\title{
Modelling of Transportation Policies to Encourage Shifting from Private Car to the Public Transport Usage in Putrajaya
}

\author{
(Permodelan Polisi Pengangkutan untuk Menggalakkan Anjakan daripada Kereta Persendirian \\ kepada Penggunaan Pengangkutan Awam di Putrajaya)
}

Amiruddin Ismail \& Haider Farhan Hashim*

\section{ABSTRACT}

The rapid growth of car ownership in Malaysia has led to a number of problems such as air contamination, traffic jams, numerous accidents, extensive fuel consumption and greenhouse effect. The proper solution is by increasing awareness about it and transferring to public transport. This paper includes vast information concerning main differences between workers who use train, bus or their car to go to work to Putrajaya administration area. It also contains information about creating transportation policies meant for encouraging car owners to start using bus on a regular basis. The survey lasted for more than one month and it included 220 respondents who needed to fill out three parts of the questionnaires and provide main travel characteristics, personal information, and name strategies that would inspire people to start using buses on a regular basis. The prime goal of this research is to use logistic regression for creating a model that would illustrate the transfer by using few variables such as gender, age, the level of education, occupation, travel time and cost, as well as car ownership. Education level and occupation were two most important factors that would show the possibility of shifting to public transport. The percentage of respondents who preferred using their own car to go to work or run errands is rather high at $86.1 \%$ on average. After that, there is $8.9 \%$ of bus travellers and $5 \%$ of train travellers. However, $70 \%$ of car users stated that they would use a bus in case of decreased time of bus travel and increased parking charges to RM 5 per hour.

Keywords: Cars ownership; public transport; traffic congestion; traffic modelling

\section{ABSTRAK}

Pertumbuhan pesat pemilikan kereta di Malaysia telah membawa kepada beberapa masalah seperti pencemaran udara, kesesakan lalu lintas, banyak kemalangan, penggunaan bahan api yang banyak dan kesan rumah hijau. Penyelesaian yang wajar ialah dengan meningkatkan kesedaran mengenainya dan berpindah kepada penggunaan pengangkutan awam. Kertas ini memberikan maklumat mengenai perbezaan utama di antara pekerja yang menggunakan kereta api, bas atau kereta mereka untuk pergi berkerja di kawasan pentadbiran Putrajaya. Ia juga membincangkan inisiatif membentuk dasar pengangkutan untuk menggalakkan pemilik kereta mula menggunakan bas secara tetap. Kaji selidik itu berlangsung selama lebih daripada satu bulan dan seramai 220 responden telah mengisi tiga bahagian soal selidik yang terdiri daripada ciriciri utama perjalanan, maklumat peribadi, dan menamakan strategi yang akan memberi inspirasi kepada orang ramai untuk mula menggunakan bas secara tetap. Matlamat utama kajian ini adalah untuk mewujudkan satu model yang akan menggambarkan pemindahan dengan menggunakan regresi logistik menggunakan beberapa pembolehubah sepertijantina, umur, tahap pendidikan, pekerjaan, masa perjalanan dan kos, dan juga pemilikan kereta. Tahap pendidikan dan pekerjaan merupakan dua faktor yang paling penting yang akan menunjukkan kemungkinan untuk beralih kepada pengangkutan awam. Peratusan responden yang lebih suka menggunakan kereta sendiri untuk ke tempat kerja adalah agak tinggi iaitu $86.1 \%$ secara purata. Kemudian, terdapat $8.9 \%$ merupakan pengguna bas dan $5 \%$ pengguna kereta api. Walau bagaimanapun, 70\% dari pengguna kereta menyatakan bahawa mereka akan menggunakan bas jika masa perjalanan bas menurun dan peningkatan caj letak kereta kepada RM 5 sejam.

Kata kunci: Pemilikan kereta; pengangkutan awam; kesesakan lalu lintas; pemodelan trafik

\section{INTRODUCTION}

Burhan (2011) concluded that the reasons for the enormous growth of private vehicle ownership in Malaysia for the past few decades are partly economic and population growth, as well as fast urban development and improper public transport services and its availability. According to the report from 2010, Malaysia had 28.3 million populations and even 11.7 million drivers in the register with 17.4 million private cars. The income is traditionally a great determinant of private vehicle ownership. Besides travel and household characteristics, auto vehicle financing and government policy, spatial arrangement of urban fabric has become a significant determinant of owning a vehicle. In addition, 
Shariff (2012) concluded that private vehicle ownership, which is in close connection with increased number of accidents, traffic congestion, pollution and inadequate parking spaces, is an important element of local and regional transportation policy making.

Figure 1 depicts the growth of car registrations in Malaysia from 104,075 automobiles in April to 104,114 automobiles in May of the same year i.e. 2013. The information concerning car registrations is provided by the Malaysian Road Transport Department. The report from the Road Transport Department (2013) stated that the average number of Malaysia Car Registrations is 61,585 cars for the period of time from 1988 until 2013. The highest number was 136,394 automobiles in July of 2012, while the lowest was 9,732 automobiles in May of 1988.

Car-dependent societies face numerous problems which greatly impact the traffic jam registered in Putrajaya particularly during the rush hour: air contamination, increased usage of energy resources such as gasoline and greater number of road accidents annually. Elsalam (2009) concludes that is greatly important to decrease traffic congestion and air contamination, considering that these are two main problems that affect the sustainability of cities due to the growing number of private cars caused by population and economic growth in many countries. Nurdden et al. (2007) states that besides the growing concern related to traffic congestion and air contamination, it is also necessary to establish a transportdependent society which can provide quality services. The growing number of private cars has called for costs on Malaysian environment and its economy.

Buehler \& Pucher (2012) found that one of the ways of resolving these problems is to increase public transport usage instead of private cars by including certain factors such as comfort, risk reduction, the ticket price, convenience, time and frequency of public buses daily. These types of studies have been conducted in many developed countries with the goal of encouraging people to start using public transport more. The rising public transport demand in Germany is partly caused by doubling the gasoline tax from $\$ 0.41$ per litre in 1990 to $\$ 0.88$ per litre ten years later. Additionally, the services have been greatly improved through discounted annual, semester and monthly tickets, new vehicles, regional coordination of ticketing and timetables and real-time information at stations and on vehicles.

Jing et al. (2010) reports that the government encourages the development of public transport with the policy called Public Transport Priority (PTP) which also controls, lowefficient transport means by the tax, priority for public transit on the investments, subvention, road use and land-use planning. The idea behind PTP is to increase competitiveness of public transport, meaning that travellers would change their travel arrangements in order to use public transport. Considering that the traffic in megacities is worsening day by day, this policy has become the prime rule of planning and transport management. The time spent working on the PTP, the fund used to it and the labour force engaged in making it is large, which is why is necessary to forecast its effects.
It can be of great help to the government in the process of choosing the suitable measure with the limited fund.

Riza (2004) concluded that the level of dependency of specific transportation mode is determined based on two sensitive parameters: travel behaviours and preferred choices over available means of transportation. There are a few characteristics that travellers use to determine suitability of the journey: comfort, risk, cost, speed as well as the nearness of the desired location. It is necessary to make an evaluation of the policies and the strategies necessary to formulate and encourage the change in choice of transportation means from using a private automobile to choosing Malaysian public transportation and to form certain predictions concerning the future modal shift.

\section{MATERIAL AND METHOD}

The survey included the use of the designed questionnaire in Putrajaya with the purpose of achieving the goal of the study and providing treatments for previously mentioned transportation problems. The participants in this area were asked to fill out the questionnaire. It included questions concerning people who used a car, a bus and a train and referred to mode attributes, socio-economic characteristics and demographic. The data in the survey included trip information about individuals, their socio-economic characteristics and attitudes, as well as their personal opinion concerning travel and policy system. The participants needed to provide socio-economic information such as age, education level, gender, occupation, the individual's income, household income and vehicle ownership. As for the trip information, they needed to state the purpose of the trip, travel cost, total travel time mode of travel etc.

Samples were collected for more than a month and there were 220 in total. The size of the sample is important because in case it's too large it may waste money, resources and time, while samples that are smaller than required may lead to imprecise results. Watson (2001) states that there are 3 main criteria used for determining the size of the sample: the precision level, the confidence level and the varying degree. The precision level refers to the value of the estimated population, the level of confidence represents the risk that the sample is taken within the average of the population and the varying degree refers to the attribute distribution in the population. In order to achieve the necessary level of precision, larger sample size should be taken.

According to Table 1, with $\pm 5 \%$ margin error, the sample size was taken. In this table, at a population of 25,000 the sample size needed is 171 at variability of $30 \%$, and in a population of 50,000 the sample size is 172 at variability of $30 \%$ and the current working population in Putrajaya is 35,000 (Putrajaya Holdings 2013). Since the bigger sample size will increase the accuracy of the results, so we take the sample size more than 172 for more accuracy. The researchers used (SPSS) software version 20 for data management and analysis, since this software was developed with the goal of 
TABLE 1: Finding a base sample size with $\pm 5 \%$ margin of error

\begin{tabular}{lccccc}
\hline $\begin{array}{l}\text { Variability } \\
\text { Population }\end{array}$ & $50 \%$ & $40 \%$ & $30 \%$ & $20 \%$ & $10 \%$ \\
\hline $100^{\text {e }}$ & 81 & 79 & 63 & 50 & 37 \\
125 & 96 & 93 & 72 & 56 & 40 \\
150 & 110 & 107 & 80 & 60 & 42 \\
175 & 122 & 119 & 87 & 64 & 44 \\
200 & 134 & 130 & 93 & 67 & 45 \\
225 & 144 & 140 & 98 & 70 & 46 \\
250 & 154 & 149 & 102 & 72 & 47 \\
275 & 163 & 158 & 106 & 74 & 48 \\
300 & 172 & 165 & 109 & 76 & 49 \\
325 & 180 & 173 & 113 & 77 & 50 \\
350 & 187 & 180 & 115 & 79 & 50 \\
375 & 194 & 186 & 118 & 80 & 51 \\
400 & 201 & 192 & 120 & 81 & 51 \\
425 & 207 & 197 & 122 & 82 & 51 \\
450 & 212 & 203 & 124 & 83 & 52 \\
500 & 222 & 212 & 128 & 84 & 52 \\
600 & 240 & 228 & 134 & 87 & 53 \\
700 & 255 & 242 & 138 & 88 & 54 \\
800 & 267 & 252 & 142 & 90 & 54 \\
900 & 277 & 262 & 144 & 91 & 55 \\
1,000 & 286 & 269 & 147 & 92 & 55 \\
2,000 & 333 & 311 & 158 & 96 & 57 \\
3,000 & 353 & 328 & 163 & 98 & 57 \\
4,000 & 364 & 338 & 165 & 99 & 58 \\
5,000 & 370 & 343 & 166 & 99 & 58 \\
6,000 & 375 & 347 & 167 & 100 & 58 \\
7,000 & 378 & 350 & 168 & 100 & 58 \\
8,000 & 381 & 353 & 168 & 100 & 58 \\
9,000 & 383 & 354 & 169 & 100 & 58 \\
10,000 & 385 & 356 & 169 & 100 & 58 \\
15,000 & 390 & 360 & 170 & 101 & 58 \\
20,000 & 392 & 362 & 171 & 101 & 58 \\
25,000 & 394 & 363 & 171 & 101 & 58 \\
50,000 & 397 & 366 & 172 & 101 & 58 \\
100,000 & 398 & 367 & 172 & 101 & 58 \\
\hline
\end{tabular}

Source: Watson (2001)

analysing written communication with greater reliability and efficiency. The SPSS model greatly helped with developing solutions that supported survey research about the attitudes, characteristics, beliefs and behaviours of the participants.

The main idea of SPSS inference is to take a random sample from Putrajaya commuters using the information from the sample to make inferences about Putrajaya transportation modes and characteristics such as program structure, age, income per month, sponsorship scale and household size. Logit models were used for regression analysis, since they can truthfully depict composite elements of the travel decision-making process of travellers by including relevant policy-sensitive and demographic illustrative variables. Nurdden et al. (2007) states that logit models do not assume linearity when it comes to relations between the dependent and independent variables, and they do not necessitate normal distribution of the variables. The estimate of the possibility that some event will take place is made when the independent variables are taken into consideration.
All the techniques that were used in the research for the analysis of numerical data and modelling consist of the values of the response variable, otherwise known as the dependent variable, and one or more predictors or explanatory variables, known also as independent variables. To understand the most significant factors, a binary logistic regression was used. Based on SPSS software version 20 regression models for one independent variable, logistic regression model is written as:

$$
Y(\text { Probability or event })=\frac{1}{1+e^{-\left(B_{0}+B_{1} X\right)}}
$$

In case when $B_{0}$ is an "intercept", $B_{1}, B_{2}, B_{3}$, will be "regression coefficients" of $X_{1} X_{2} X_{3}$ respectively. In case when $B_{0}$ and $B_{1}$ are the estimated parameters or coefficients from data - a scalar, $X$ is the independent variable - a vector, and $e$ is the basic logarithm value -2.7182818 . When there are more than two predictors, the logistic regression model should be presented according to the Wikipedia Organization Logistic function (online 17 Sept 2007) this way:

$$
Y(\text { Probability or event })=\frac{1}{1+e^{-v}}
$$

Where $v$ is the regression equation, $e=2.7182818$,

And $\quad v=B_{0}+B_{1} X_{1}+B_{2} X_{2}+\ldots . .+B_{p} X_{p}$

Parameters from the data which is a scalar, $X_{1}, X_{2}, \ldots, X_{p}$ are predictors which is a vector, and $\mathrm{p}$ represents the number of independent variables. In case when the probability value is less than 0.5 , the conclusion is that the event did not occur but when probability gets larger than 0.5 , the conclusion is that the event did occur. The binary logit model (binary logit regression) was used with the goal to determine the probability of car users shifting to buses by making assessment of these few independent variables: age, level of education, gender, occupation, travel cost and time. Validation process was conducted to correlate our survey data with the model in order to measure correlation between dependent variable and independent variable. Adopting binary logit model of the proposed model is to test sensitivity.

\section{RESULTS FROM DATA ANALYSIS}

The research took place in the administrative area of Putrajaya and it consisted of two parts. First was in relation to policy measures, attitudes and perceptions of travel, the socioeconomic characteristics of public transport users and travel information. It included information concerning age, level of education, occupation, sex, car ownership and income of individuals and households. The other part referred to the behaviour of car drivers and the potential of shifting to public transport.

The demographic analysis from Table 2 shows that all the participants in the study were Malaysian, $57.2 \%$ participants were male and the rest were female participants. The group 
TABLE 2. Demographic analysis of the survey

\begin{tabular}{ccc}
\hline Variables & Attribute & Percentage \\
\hline Gender & male & 57.2 \\
& Female & 42.8 \\
Age & Less than 23 & 11.7 \\
& $23-34$ & 61.7 \\
& $35-46$ & 9.4 \\
& $47-53$ & 13.3 \\
Nationality & more than 53 & 3.9 \\
& Malaysian & 100.0 \\
Occupation & Non-Malaysian & 0.0 \\
& Full Time & 30.6 \\
& Part Time & 26.1 \\
& Self Employed & 21.1 \\
& Housewife & 16.1 \\
Household Size & Unemployment & 6.1 \\
& 1 to 3 persons & 46.1 \\
& 4 to 6 persons & 41.1 \\
& more than 6 persons & 12.8 \\
\hline
\end{tabular}

included participants that were between 23 and 34 years old, an average of $61.7 \%$ in total. Most of them were employed full time, the average is $30.6 \%$, and there were $26.1 \%$ part-time employees. The responses showed that $46.1 \%$ of participants lived with one to three persons, while $12.8 \%$ lived with more than 6 persons in their house.

As for the preferred travel mode, $86.1 \%$ of participants revealed that they prefer using their car for going to work and running errands, while only $8.9 \%$ of participants stated that they prefer to use the bus as shown in Table 3. Table 4 focused on the major factors which make the respondents to use a car instead of public transportation. The leading factors considered were reliability, satisfaction, comfort level, flexibility, safety and prestige. Based on the responses received majority of them preferred comfort and at $48.3 \%$ as it rains pretty often in Malaysia and this was followed by flexibility and convenience at $25 \%$ the rest others opted for prestige, reliability and safety.
TABLE 3. Mode of travel preferred by commuters

\begin{tabular}{cc}
\hline Travel Mode & Percentage \\
\hline car & 86.1 \\
bus & 8.9 \\
Train & 5.0 \\
\hline Total & 100.0 \\
\hline
\end{tabular}

TABLE 4. Factors encouraging car use

\begin{tabular}{lc}
\hline Factor & Percentage \\
\hline Its Reliable & 3.3 \\
Its Satisfactory & 4.4 \\
Comfort and Weather Convenience & 48.4 \\
Flexible \& Convenient & 25.0 \\
Safety & 15.0 \\
Prestigious & 3.9 \\
\hline
\end{tabular}

Table 5 reveals factors that most likely will Make People to use public transport. A total of $55.6 \%$ of respondents are ready to switch to public transport in case if there is an increase in accessibility and $22.2 \%$ mentioned that they would switch in case if there is an increase in comfort level. Figure 2 explains the factors that discourage the respondents from use the public transport, most of them mentioned that desirable routes are not covered and some also replied that the service is lacking of frequency. The attitude of the respondents towards the public transportation was illustrated in Figure 3 ; the majority of them (32.2\%) mentioned that they would feel inconvenient.

This research sheds more light to the enforcement of policy changes in relation to driving license age; travel time and parking charges could impact the private car users. It was revealed that even $52 \%$ of users would start using a public transportation when parking charge increase to RM 5 per hour, which is shown in the Figure 4 . Up to $70 \%$ of

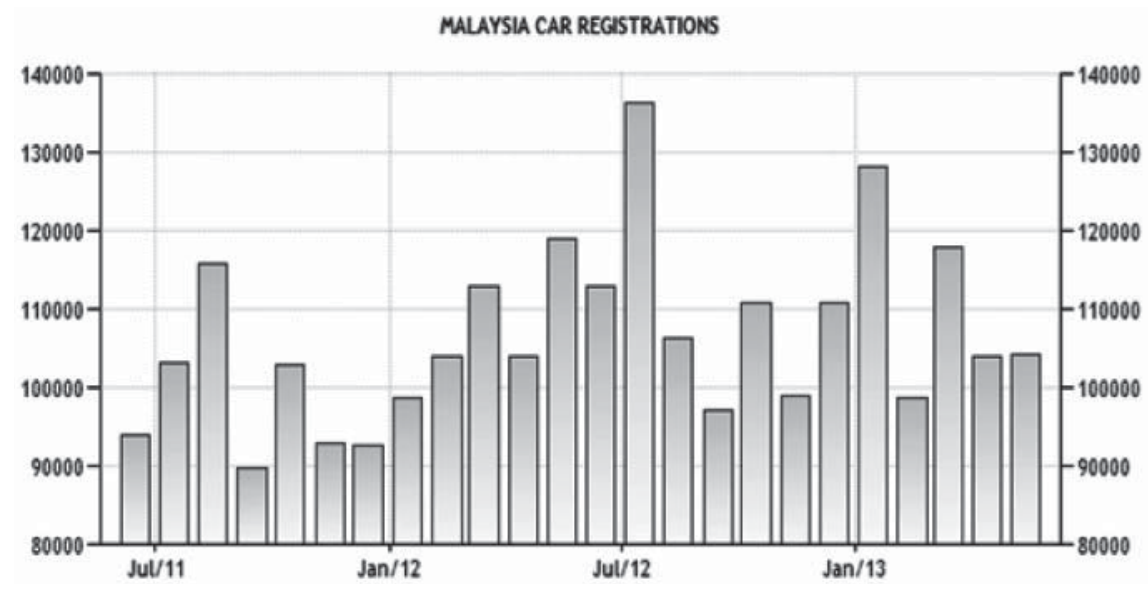

FIGURE 1. Statistics of registered vehicles in Malaysia until Jul. 2013

Source: Road Transport Department 2013 
TABLE 5. Factors that most likely will make people to public transport

\begin{tabular}{lc}
\hline Factor & Percentage \\
\hline If the service is faster & 7.8 \\
If the fare is considerably Cheap & 13.9 \\
If the service is Comfortable & 22.2 \\
If it is safe & 0.6 \\
If the route is more accessible & 55.5 \\
Prestigious & 3.9 \\
\hline
\end{tabular}

Factors discouraging public transport

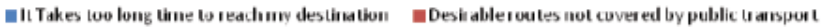
= unfrequented public transport Evehides are too crowded

=uncomfortable

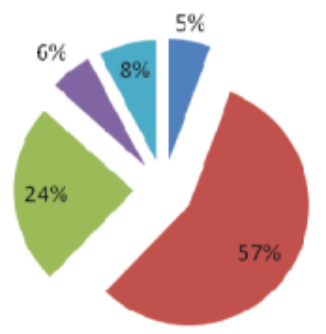

FIGURE 2. Factors discouraging public transport

\section{Attitude towards Public transportation}

=Inconvinient $=$ Indifferent $=$ Very Convinient $=$ Very Inconvinient

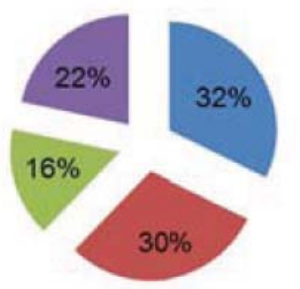

FIGURE 3. Attitudes towards public transportation

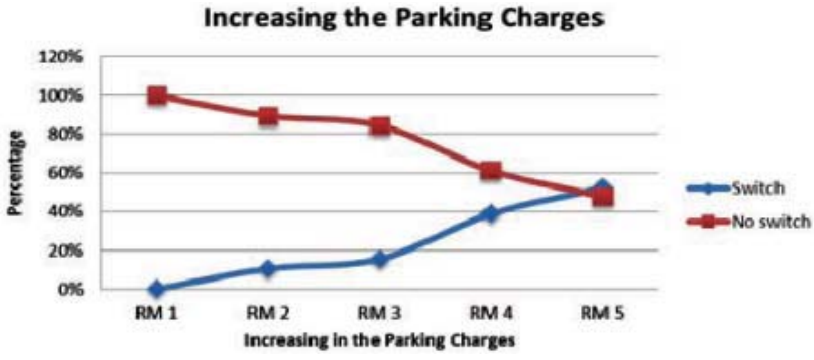

FIGURE 4. Increasing the parking charges

travellers would start using a bus instead of their car in case of the travel time reduction of $60 \%$, which is shown in Figure 5. In case of the driving license change from eighteen

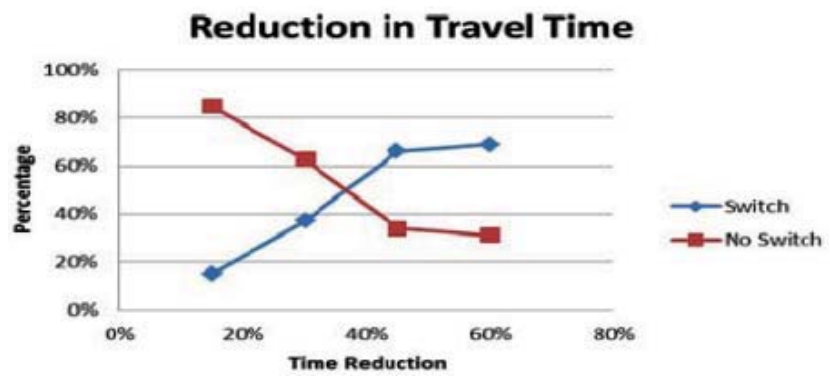

FIGURE 5. Travel time reduction

to twenty-three years old, up to $63 \%$ travellers would shift to motorcycle.

\section{MODELLING}

Important factors considered were the travel time, travel cost and the frequency of public transport service and travel time factor was selected as the prime factor by the respondents (see Figure 5). Therefore the modeling activity focused more on the travel time factor as developed using Table 6 and equation 3 , two independent variables were significant factors such as (occupation and education level), while other variables such as age, gender, registered car, travel time, travel cost, and driving license were not significant at (sig. value) $<0.05$. The derived model is shown below:

$$
v=-0.457 * \text { Occupation }+0.613 * \text { Education }
$$

TABLE 6. Significant variables in modelling

\begin{tabular}{|c|c|c|c|c|c|c|c|}
\hline & & \multicolumn{4}{|c|}{ Variables in the Equation } & \multirow[b]{2}{*}{ Sig. } & \multirow[b]{2}{*}{$\operatorname{Exp}(B)$} \\
\hline & & $\mathrm{B}$ & S.E. & Wald & df & & \\
\hline Step & Age & .099 & .243 & .166 & 1 & .683 & 1.104 \\
\hline \multirow[t]{8}{*}{$1^{\mathrm{a}}$} & Gender & .518 & .475 & 1.189 & 1 & .276 & 1.679 \\
\hline & $\begin{array}{l}\text { Registered } \\
\text { cars }\end{array}$ & .336 & .367 & .839 & 1 & .360 & 1.400 \\
\hline & Occupation & -.457 & .185 & 6.131 & 1 & .013 & .633 \\
\hline & Education & .613 & .375 & 2.668 & 1 & .002 & 1.846 \\
\hline & License & .436 & .489 & .783 & 1 & .461 & 1.503 \\
\hline & $\begin{array}{l}\text { Travel time } \\
\text { by car }\end{array}$ & -.304 & .338 & .809 & 1 & .368 & .738 \\
\hline & Cost by car & .293 & .382 & .586 & 1 & .444 & 1.340 \\
\hline & Constant & .398 & 1.912 & .043 & 1 & .835 & 1.488 \\
\hline
\end{tabular}

Table 7 shows that a total of 180 respondents were considered as an actual study and 40 respondents were considered for the validation study to correlate the proposed model.

PROBABILITY PREDICTION

The probability of car users shifting to the public transport by reducing the travel time was examined depending on 
TABLE 7. Model validation

\begin{tabular}{llcccc}
\hline & & $\mathrm{B}$ & $\mathrm{P}(\mathrm{n}=180)$ & $\mathrm{B}$ & $\mathrm{P}(\mathrm{n}=40)$ \\
\hline Step & Age & .099 & .683 & .109 & .713 \\
$\mathrm{1}^{\mathrm{a}}$ & Gender & .518 & .276 & .568 & .233 \\
& Registered & .336 & .360 & .346 & .319 \\
& cars & & & & \\
Occupation & -.457 & .013 & -.372 & .023 \\
Education & .613 & .002 & .593 & .011 \\
License & .436 & .461 & .487 & .423 \\
Travel time & -.304 & .368 & -.295 & .298 \\
by car & & & & \\
Cost by car & .293 & .444 & .302 & .419 \\
Constant & 0.398 & .835 & 0.433 & .634 \\
\hline
\end{tabular}

equations 4 and 2, and controlling the two variables by keeping them constant as follow:

$$
\begin{aligned}
v & =-0.457 * \text { Occupation }+0.613 * \text { Educations } \\
& =-0.457 *(1)+0.613 *(1) \\
v & =0.156 \\
P & =1 / 1+\mathrm{e}^{-\mathrm{v}} \\
P & =1 / 1+\mathrm{e}^{-(0.156)} \\
P & =0.54
\end{aligned}
$$

Therefore, mode shift to public transport is proven since the value of 0.54 is more than the cut-off point of 0.5 .

\section{MODEL SENSITIVITY TEST}

A model sensitivity test was done to check the suitability of the proposed model. For this purpose a model sensitivity test was carried out by using the derived equations 4 and 2 along with the values predicted in the coding Table 8 . Based on that analysis $P_{1}$ was considered to be the best model in comparison to $P_{2}$. The following calculations show the details.

$$
\begin{aligned}
& V_{1}=-0.457 * \text { Occupation }+0.613 * \text { Educations } \\
& V_{1}=0.156 \\
& P_{1}=1 / 1+e^{-(0.156)} \\
& P_{1}=0.54 \\
& V_{2}=-0.457 *(5)+0.613 *(3) \\
& V_{2}=-0.446 \\
& P_{2}=1 / 1+e^{-(-0.446)} \\
& P_{2}=0.2807
\end{aligned}
$$

TABLE 8. Explanatory variable for data collection codding in SPSS

\begin{tabular}{lcc}
\hline Variables & Attribute & Code Data \\
\hline Occupation & Full time & 1 \\
& Part time & 2 \\
& Self-employed & 3 \\
& Housewife & 4 \\
Education level & Unemployed & 5 \\
& Primary & 1 \\
& Secondary & 2 \\
& College & 3 \\
\hline
\end{tabular}

The given values for $P_{1}$ and $P_{2}$ showed that $P_{1}>P_{2}$ and $P_{1}$ is more than 0.5 , while $P_{2}$ is less than 0.5 which indicates that that the proposed model is suitable for this study.

\section{CONCLUSION}

The main target of this paper is to investigate the facilities that encourage people to use public transport (bus) in Putrajaya. The survey revealed that the most important factors affected decision making in choosing travel mode was travel time since $70 \%$ of respondents decided to shift to bus transit use when the reduction in travel time was $60 \%$, while the other factor was the parking charge as $52 \%$ of people replied to shift to bus use when the parking charge increase to RM 5 per hour. Since the travel time factor was primarily considered by the respondents, the travel mode model is created to explain modal shift to bus and $54 \%$ of car users were predicted to shifting. The analysis of results showed that the commuters behavior in transport mode choice influenced by some other factors, the most effectiveness factor that influence on people and make them prefer using public transport (bus) is the accessibility of rout with $55.5 \%$, while the most effectiveness factors that discourage public transport use (bus) was (not covered by public transport) with $56.7 \%$, also the attitude towards public transport was mentioned that $32.2 \%$ of people felt inconvenient. Therefore the concerned authorities should focus on reducing the travel time by improving frequency of buses, and on discouraging car users by increasing parking charges. Other aspects such as convenience and accessibility are important but appear to be less significant compared to the first two factors.

\section{REFERENCES}

Borhan, M. N., Ismail, A., Rahmat, R. A. O. \& Ambak, K. 2011. Effect of transport policies to shifting private car users to park-and-ride in Putrajaya, Malaysia. Australian Journal of Basic \& Applied Sciences 5(3): 303-308.

Buehler, R. \& Pucher, J. 2012. Demand for public transport in Germany and the USA: An analysis of rider characteristics. Transport Reviews 32(5): 541-567.

Elslam, H. M. 2009. Influence of post graduate students in UKM to use public transport. Unpublished M. Eng. Thesis. Faculty of Engineering and Built Environment. Universiti Kebangsaan Malaysia. Bangi.

Jing, Y., Rui, Z., Hai-Yan, W. \& Bao-Hua, M. 2010. Forecasting the effect of ptp policy on changes of travel patterns with ordered logit model. Computer Application and System Modeling (ICCASM), 2010 International Conference on, pp. V11-296-V211-301.

Nurdden, A., Rahmat, R. \& Ismail, A. 2007. Effect of transportation policies on modal shift from private car to public transport in Malaysia. Journal of Applied Sciences 7(7): 1013-1018.

Putrajaya Holdings. 2013. Putrajaya Holding. Retrieved on: 3 Sept. 2013. http://www.pjh.com.my/corporate/ putrajaya-facts/ 
Riza, A. 2004. Urban Transport Management System. Engineering Faculty, UKM IRPA 0, 4-02.

Road Transport Department. 2013. Road Transport Department. Retrieved on: 29 September 2013. http:// www.tradingeconomics.com.

Shariff, N. 2012. Private Vehicle Ownership and Transportation Planning in Malaysia. Singapore, International Conference on Traffic and Transportation Engineering, 64-68.

Watson, J. 2001. How to Determine a Sample Size: Tipsheet\#60, University Who Europe. (2011). Health economic assessment tools (HEAT) for walking and cycling: Economic assessment of transport infrastructure and policies. Geneva: World Health Organization.

\section{Amiruddin Ismail}

Sustainable Urban Transport Research Centre (SUTRA),

Department of Civil and Structural Engineering

Faculty of Engineering and Built Environment

Universiti Kebangsaan Malaysia

43600 Bangi, Selangor

Haider Farhan Hashim*

Department of Civil and Structural Engineering,

Faculty of Engineering and Built Environment

Universiti Kebangsaan Malaysia

43600 Bangi, Selangor

*Corresponding author; email: haider.hashim70@yahoo. com

Received Date: $22^{\text {nd }}$ May 2014

Accepted Date: $14^{\text {th }}$ April 2015
Wikipedia Organization. Logistic function Wikipedia Organization. Retrieved on: 17 September 2007. http:/ en. wikipedia.org/wiki/Logistic function.

Hashim, F. 2014. Modal Shift Model for Public Transportation in Putrajaya. Unpublished Master Project Report. 